\title{
THE INFLUENCE OF WORK ETHICS, WORK ENGAGEMENT AND PERSONALITY ON EMPLOYEE PERFORMANCE
}

\author{
Jufrizen*1, Virza Erika \\ ${ }^{1,2}$ Faculty of Economics and Business, Universitas Muhammadiyah Sumatera Utara \\ E-mail: jufrizen@umsu.ac.id
}

\begin{abstract}
The purpose of this study was to determine and analyze the effect of work ethics, work involvement and personality on employee performance (study at the Medan City Regional Tax and Retribution Management Agency). The approach used in this study is an associative approach. The population in this study were employees of the Medan City Regional Tax and Retribution Management Agency)., A total of 32 employees while the sample in this study used Nonprobability sampling or Saturated Sampling as many as 32 Employees. The data collection technique in this study used a questionnaire technique by distributing questionnaires. The data analysis technique in this study uses Multiple Linear Regression Test, Hypothesis Testing (T Test and F Test), and Coefficient of Determination. Data processing in this study using IBM SPSS Statistic 23 software program. The results of this study prove that partially work ethics (XI) has an effect on performance $(Y)$ with t-test work ethics $(X 1)$ $1.954>$ ttable 1.693 with sig $0.008<0,05$, and Work Involvement $(X 2) 2,348>t$ table 1,693 with sig 0,089 < 0,05. and Personality (X3) 1,880 > ttable 1,693 with sig 0,006 <0,05. The results of this study prove that simultaneously Fcount $7.142>$ Ftable 4.20 with $R$ Square 0.509 or $50.9 \%$ which means that there is an influence of work ethics.
\end{abstract}

Keywords: Work Ethics, Work Involvement, Personality and Performance

\section{INTRODUCTION}

Human resources are the basis for the efficient and effective implementation of HRM processes in achieving organizational/company goals. In the times and increasingly fierce competition, every organization is required to be able to create quality human resources and be able to compete. The main factor needed in order to realize the expectations of the organization is the human resource factor. The problem of human resources is still in the spotlight and the foundation for companies to survive in the era of globalization (Aini \& Suhermin, 2016). The quality of human resources is not only assessed in terms of intellectual property, but behavior and attitudes are very important things that need to be detected for companies so that the company's organizational wheels can run well and produce good performance as well.

The performance of an organization is largely determined by the human resources in it. If human resources have a work ethic, personality and contribution to work involvement who are competent in the company and are able to develop innovation, their performance will be better. Therefore, efforts are needed to improve the ability of human resources for satisfactory performance results.According to (Fiernaningsih, 2017) Performance is the result of work in quality and quantity that can be achieved by an employee in carrying out tasks in accordance with the responsibilities given to him. Several factors that can affect employee performance include personality, work involvement, and work ethic. Based on the results of research conducted by researchers at the Medan City Regional Tax and Retribution Management Agency, namely where there is employee performance that is not optimal during the covid pandemic, where employees are required to work 
The Influence of Work Ethics, Work Involvement and Personality on Employee Performance virzaerika@gmail.com

more by carrying out health protocols and employees are required to work fast, while the situation during the pandemic is all activities are limited, and services to the community are not optimal.

To have a good performance the company must also develop a good personality towards its employees. Personality is an important thing that influences work behavior. Personality can encourage a positive work behavior. This is expressed through attitudes and has an important meaning in organizational behavior, because employees whose attitudes are positive towards their work tend to produce better performance than employees whose attitudes are neutral or negative towards their work. (Rum, Sendow, \& Pandowo, 2019). Based on the results of pre-research conducted at the Medan City Regional Tax and Retribution Management Agency, there are personality problems, where employees are less harmonious between co-workers, this occurs due to lack of coordination and communication between co-workers, so this becomes a personality problem for individuals to form good performance in the organization. Factors that shape personality in improving performance are also influenced by work involvement. Employee involvement in achieving organizational goals is very important. By involving employees, all components in an institution or organization may produce better plans and results. In addition, everyone's involvement will accelerate achieving organizational goals. According to (Stephen P. Robbins \& Judge,

Based on the results of pre-research conducted by researchers at the Medan City Regional Tax and Retribution Management Agency, there are problems with employee work involvement in making decisions when conducting meetings, besides the lack of training provided to develop skills in work involvement in serving the community is an obstacle for employees in carrying out their duties and obligations. which has been given. In addition to work involvement, a factor that can affect performance is work ethic, where work ethic is also very influential on employee performance. In fostering the ability to work and improve employee performance, it is certainly inseparable from work ethics. Work ethics are attitudes, views, habits, characteristics or traits regarding the way of working that a person, a group, or a nation has. The things that underlie a high work ethic include the desire to uphold the quality of work, so individuals who have a high work ethic will also provide input for ideas in the workplace. (Budianto, Pongtuluran, \& Y, 2018).

As for the phenomenon of other problems for employees of the Medan City Regional Tax and Retribution Management Agency, namely work ethics, where there are employees who do not comply with organizational regulations, such as employees receiving bribes to facilitate business, there are employees smoking in the office environment, there are employees late for work after break time. afternoon, so this causes a decline in the performance of the Medan City Regional Tax and Retribution Management Agency. Based on the results of research conducted by researchers at the Regional Tax and Retribution Management Agency of Medan City, it can be concluded that the problems that occur are where there is employee performance that is not optimal during the covid pandemic, where employees are required to work more by implementing health protocols and employees are required to work fast,

There are problems with employee work involvement in making decisions when conducting meetings, besides the lack of training provided to develop skills in work involvement in serving the community is an obstacle for employees in carrying out the tasks and obligations that have been given. Problems with the personality of employees occur because employees are less harmonious between co-workers, this happens because of a lack of coordination and communication between coworkers, so this becomes a personality problem for individuals to form good performance in the organization. 


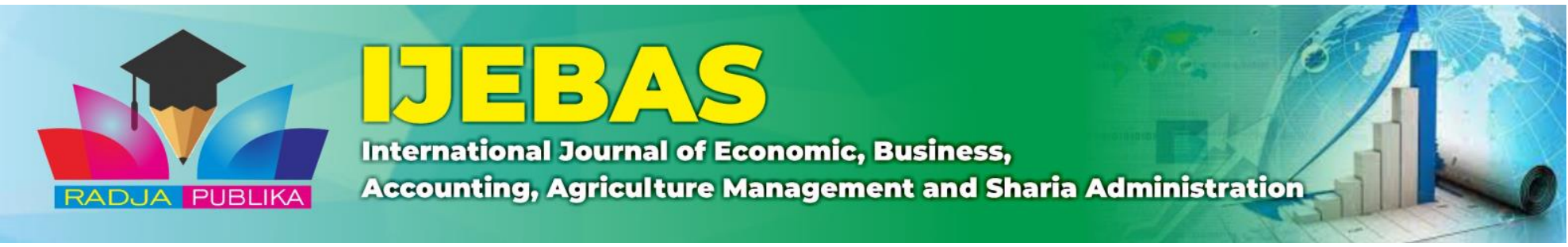

\section{RESEARCH METHOD}

The method used is associative research method. The population of this research is the employees of the Medan City Regional Tax and Retribution Management Agency as many as 32 employees. This research was conducted in May 2021 - September 2021. The variables used in this study include the independent variables, namely work ethics, work involvement and personality with the dependent variable being employee performance. Determination of sampling using nonprobability sampling method. The sampling technique in this study used saturated sampling. Data analysis techniques in this study include data quality tests (validity and reliability tests), classical assumption tests, multiple linear regression and hypothesis testing. The data analysis technique was carried out using the SPSS 23 program.

Work ethic According to (Aryana \& Winoto, 2017) Work ethic is a positive behavior that learns about the norms of a group in a work paradigm. Where indicators on work ethics used are a sense of responsibility, hard work, thrifty and respect for time. Job involvement according to (Safaria, 2013 ) is the relationship between work involvement and individuals in a deep and complex manner, both running by achieving the value of work which is a source of income. The indicators used are work participation, participation and cooperation. Personality according to (Hanggraeni, 2011) is a set of ways in which an individual breaks and interacts with other people. The indicators used in personality are broad insight, fun, thoroughness, emotional stability and openness to experience. Employee performance according to (AAP Mangkunegara, 2014) says that performance is the result of work in quality and quantity achieved by an employee in carrying out his duties in accordance with the responsibilities given to him. The indicators used include work quality, work quantity, work reliability and attitude.

\section{RESULTS AND DISCUSSION}

Regression analysis is used to determine whether there is an influence between variables. The following is a summary of the results of simple and multiple regression analysis and path analysis.

Table 1. Results of Simple Regression Analysis

\begin{tabular}{|c|c|c|c|c|c|c|c|c|}
\hline \multirow{2}{*}{\multicolumn{2}{|c|}{ Model }} & \multicolumn{2}{|c|}{$\begin{array}{c}\text { Unstandardized } \\
\text { Coefficients }\end{array}$} & \multirow{2}{*}{$\begin{array}{c}\begin{array}{c}\text { Standardized } \\
\text { Coefficients }\end{array} \\
\text { Beta }\end{array}$} & \multirow[t]{2}{*}{$\mathrm{t}$} & \multirow[t]{2}{*}{ Sig. } & \multicolumn{2}{|c|}{$\begin{array}{l}\text { Collinearity } \\
\text { Statistics }\end{array}$} \\
\hline & & B & Std. Error & & & & Tolerance & VIF \\
\hline \multirow[t]{4}{*}{1} & (Constant) & 42,492 & 9,610 & & 4,422 & , 000 & & \\
\hline & Work Ethics &, 112 &, 117 & ,192 & 1,954 & ,008 & ,784 & 1.275 \\
\hline & Work Engagement & ,124 & ,092 & 252 & 2,348 &, 089 & 912 & 1.096 \\
\hline & Personality & ,093 & ,105 & 182 & 1,880 & ,006 & ,746 & 1,340 \\
\hline
\end{tabular}

a. Dependent Variable: Performance

Source: SPSS Output

Based on table 1, it can be seen that the variables X1, X2 and X3 have a VIF value within a predetermined tolerance limit (not exceeding 4 or 5), so there is no multicollinearity in the independent variables of this study. 
Volumes 1 No 1 (2021)

The Influence of Work Ethics, Work Involvement and Personality on Employee Performance

virzaerika@gmail.com

Table 2. Results of Multiple Regression Analysis

\begin{tabular}{|c|c|c|c|c|c|c|c|}
\hline \multirow{2}{*}{ Model } & \multicolumn{2}{|c|}{$\begin{array}{l}\text { Unstandardized } \\
\text { Coefficients }\end{array}$} & \multirow{2}{*}{$\begin{array}{c}\begin{array}{c}\text { Standardized } \\
\text { Coefficients }\end{array} \\
\text { Beta }\end{array}$} & \multirow{2}{*}{$\mathrm{t}$} & \multirow{2}{*}{ Sig. } & \multicolumn{2}{|c|}{ Collinearity Statistics } \\
\hline & B & $\begin{array}{l}\text { Std. } \\
\text { Error }\end{array}$ & & & & Tolerance & VIF \\
\hline (Constant) & 42,492 & 9,610 & & 4,422 &, 000 & & \\
\hline Work Ethics &, 112 &, 117 & ,192 & 1,954 &, 008 & ,784 & 1.275 \\
\hline $\begin{array}{l}\text { Work } \\
\text { Engagement }\end{array}$ &, 124 & ,092 & 252 & 2,348 & 089 & ,912 & 1.096 \\
\hline Personality &, 093 &, 105 &, 182 & 1,880 & ,006 & ,746 & 1,340 \\
\hline
\end{tabular}

a. Dependent Variable: Performance (Y)

\section{Source: SPSS Output}

Based on table 2, it can be seen that the work ethic obtained tcount of 1.954 with a significant value of 0.008 while the value of the provisions for 32 samples ttable of 1.693 with a significant value of 0.05 . The conclusion is tcount $1.954>$ ttable 1.693 with a significant value of $0.008<0.05$ then $\mathrm{Ho}$ is rejected and $\mathrm{Ha}$ is accepted, which means that partially work ethics have a significant effect on employee performance at the Medan City Regional Tax and Retribution Management Agency.

Table 3. Effect of work ethic, work involvement and personality on performance

\begin{tabular}{|c|c|c|c|c|c|}
\hline Model & $\mathrm{R}$ & R Square & $\begin{array}{c}\text { Adjusted F } \\
\text { Square }\end{array}$ & $\begin{array}{l}\text { Std. Error of } \\
\text { the Estimate }\end{array}$ & $\begin{array}{l}\text { Durbin- } \\
\text { Watson }\end{array}$ \\
\hline & 530 & ,509 & 0.014 & 1.00464 & 2,341 \\
\hline
\end{tabular}

a. Predictors: (Constant), Personality (X3), Job Involvement (X2), Work Ethics (X1)

b. Dependent Variable: Performance (Y)

Based on table 3, it can be seen that the $\mathrm{R}$ value is 0.530 and the $\mathrm{R}$-Square is 0.509 or $50.9 \%$. From the R-Square value, it can be seen that together work ethics, work involvement and personality. It has an influence of $50.9 \%$, while the remaining $49.1 \%$ is influenced by other factors outside this study.

\section{CONCLUSION}

From the research conducted, the following results were found: 1) Work ethic partially has a positive and significant effect on employee performance at the Regional Tax and Retribution Management Agency of Medan City. 2) Partially positive and significant work involvement on employee performance at the Medan City Regional Tax and Retribution Management Agency. 3) Partially positive and significant personality towards employee performance at the Medan City Regional Tax and Retribution Management Agency. 4) Simultaneously Work Ethics, Work Involvement, and Personality are positive and significant on Employee Performance at the Regional Tax and Levy Management Agency of Medan City.

From the results of this study, suggestions can be given, firstly, the Medan City Tax and Levy Management Agency should tighten the work ethic in the organization so that existing regulations will be obeyed and run well, the Medan City Tax and Levy Management Agency should involve all employees in carrying out their duties and responsibilities. responsibility in achieving the vision and mission, so that work involvement in work will affect and improve the performance of 
employees, the Medan City Tax and Retribution Management Agency should pay attention to the personality of employees in working both in service and team work at work, so as to create a good personality in order to achieve vision and mission. Second, for further researchers so that it can be a guideline / reference for conducting more in-depth research on the contribution of the variables of Work Ethics, Work Involvement and Personality to Employee Performance. And it is recommended for further researchers to be able to conduct research by looking at the correlation of the factors that affect employee performance. In addition, for the Regional Tax and Levy Management Agency of Medan City, the results of this study should be taken into consideration to improve employee performance. The results of this study indicate a positive value which means that if the Work Ethics, Work Involvement and Personality are improved, the performance will also increase. And it is recommended for further researchers to be able to conduct research by looking at the correlation of the factors that affect employee performance. In addition, for the Regional Tax and Levy Management Agency of Medan City, the results of this study should be taken into consideration to improve employee performance. The results of this study indicate a positive value which means that if the Work Ethics, Work Involvement and Personality are improved, the performance will also increase. And it is recommended for further researchers to be able to conduct research by looking at the correlation of the factors that affect employee performance. In addition, for the Regional Tax and Levy Management Agency of Medan City, the results of this study should be taken into consideration to improve employee performance. The results of this study indicate a positive value which means that if the Work Ethics, Work Involvement and Personality are improved, the performance will also increase.

\section{REFERENCE}

Aini, N., \& Suhermin, S. (2016). Pengaruh Motivasi, Komitmen Organisasi, OCB Dan Disiplin Kerja Terhadap Kinerja Pegawai. Jurnal Ilmu Dan Riset Manajemen, 5(9), 115.

Amelia, L. J. (2018). Faktor Pribadi dan Kepuasan Kerja Sebagai Penentu Tercapainya Kinerja Pegawai. Ilmiah Magister Ilmu Administrasi (JIMIA), (1), 1-16.

Aryana, P., \& Winoto, H. (2017). Pengaruh Budaya Organisasi, Etika Kerja dan Loyalitas terhada Kinerja Pegawai (Studi kasus pada Pegawai pendukung non akademik Universitas XYZ). Ilmiah Manajemen Bisnis, 17(2), 89-110.

Bertens, K. (2000). Pengantar Etika Bisnis. Jakarta: PT. Gramedia Pustaka Utama.

Budianto, A., Pongtuluran, Y., \& Y, S. (2018). Pengaruh etika kerja, motivasi kerja dan kompensasi finansial terhadap kinerja Pegawai. Kinerja, 14(1), 1. https://doi.org/10.29264/jkin.v14i1.2472

Cilliana, C. (2008). Pengaruh Kepuasan Kerja, Keterlibatan Kerja, Stres Kerja, dan Komitmen Organisasi Terhadap Kesiapan Untuk Berubah Pada Pegawai PT Bank Y. : Fakultas Psikologi Universitas Indonesia.

Dalimunthe, A. A. (2020). Pengaruh Etika Kerja, Pengalaman Kerja, dan Budaya Kerja Pegawai Badan Kesatuan Bangsa, Politik dan Perlindungan Masyarakat Kabupaten Karo. Jurnal Manajemen Tools, 12(2), 14-29.

Ernawan, R. E. (2007). Business Ethics. Bandung: Alfabeta.

Ferri, A., Muhammad, A., \& Mahdani, I. (2017). Pengaruh Keterlibatan Kerja,Beban Kerja dan Konflik Peran Terhadap Kepuasan Kerja Serta Dampaknya Pada Kinerja Pegawai Pada Dinas Pendidikan Aceh. Manajemen Dan Inovasi, 8(2), 84-96.

Fiernaningsih, N. (2017). Pengaruh Kepribadian Terhadap Kinerja Pegawai Di Hotel Elresas Lamongan. Adbis: Jurnal Administrasi Dan Bisnis, 11(2), 221. https://doi.org/10.33795/j-adbis.v11i2.32

Fitriyani, D., Sundari, O., \& Dongoran, J. (2019). Faktor-Faktor Yang Mempengaruhi Etos 
The Influence of Work Ethics, Work Involvement and Personality on Employee Performance virzaerika@gmail.com

Kerja Pegawai Kecamatan Sidorejo Salatiga. Jurnal Ilmu Sosial Dan Humaniora, 8(1), 24. https://doi.org/10.23887/jish-undiksha.v8i1.21351

Gibson, J. (2007). Organizations: Behavior,Structure,Processes. New York: McGraw-Hill Irwin.

Hanggraeni, D. (2011). Perilaku Organisasi. Jakarta: Lembaga Penerbit Fakultas Ekonomi UI.

Harahap, S. F., \& Tirtayasa, S. (2020). Pengaruh Motivasi, Disiplin, Dan Kepuasan Kerja Terhadap Kinerja Pegawai Di PT. Angkasa Pura II (Persero) Kantor Cabang Kualanamu. Maneggio: Jurnal Ilmiah Magister Manajemen, 3(1), 120-135. https://doi.org/10.30596/maneggio.v3i1.4866

Humaira, I., \& Sagoro, E. M. (2018). Pengaruh Pengetahuan Keuangan, Sikap Keuangan, Dan Kepribadian Terhadap Perilaku Manajemen Keuangan Pada Pelaku Umkm Sentra Kerajinan Batik Kabupaten Bantul. Nominal, Barometer Riset Akuntansi Dan Manajemen, 7(1), 96-110. https://doi.org/10.21831/nominal.v7i1.19363

Indrawan, M. I. (2017). Pengaruh Etika Kerja, Pengalaman Kerja dan Budaya Kerja Terhadap Prestasi Kerja Pegawai Kecamatan Binjai Selatan. Journal Abdi Ilmu, 10(2), 1851-1858.

Indriyati, I. S. (2017). Pengaruh Gaya Kepemimpinan, Motivasi kerja, dan Disiplin Kerja Terhadap Kinerja Pegawai Dengan Pemahaman Etika Kerja Islami. UPAJIWA DEWANTARA: Jurnal Ekonomi, Bisnis Dan Manajemen Daulat Rakyat, 1(2), 1-13. https://doi.org/10.26460/mmud.v1i2.1990

Istijanto. (2005). Riset Sumber Daya Manusia. Jakarta: PT. Gramedia Pustaka Umum.

Iswandari, A. (2013). Pengaruh Motivasi Intrinsik, Pengetahuan Kewirausahaan, Dan Kepribadian Terhadap Minat Berwirausaha Pada Siswa Smkn 12 Surabaya. Jurnal Ekonomi Pendidikan Dan Kewirausahaan, 1(2), 152-162.

Jufrizen, J. (2016). Efek Mediasi Kepuasan Kerja Pada Pengaruh Kompensasi Terhadap Kinerja Pegawai. Jurnal Ilmiah Manajemen Dan Bisnis, 17(1).

Jufrizen, J. (2017). Efek Moderasi Etika Kerja Pada Pengaruh Kepemimpinan Transformasional dan Budaya Organisasi Terhadap Kinerja Pegawai. E-Mabis : Jurnal Ekonomi Manajemen Dan Bisnis, 18(2), 145-158. https://doi.org/10.29103/emabis.v18i2.180

Jufrizen, J., Gultom, D. K., Sitorus, S. A., Sari, M., \& Nasution, M. I. (2018). The Effect of Organizational Culture and Islamic Work Ethic on Permanent Lecturers' Job Satisfaction, Organizational Commitment And Work Performance at Private Islamic Universities in the City of Medan. Proceeding 1st International Conference of Economic Studies (ICOES) 2018, 179-186.

Jufrizen, J., Lumbanraja, P., Salim, S. R. A., \& Gultom, P. (2017). The Effect of Compensation, Organizational Culture and Islamic Work Ethic Towards the Job Satisfaction and the Impact on the Permanent Lecturers. International Business Management, 11(1), 53-60.

Juliandi, A., Irfan, I., \& Manurung, S. (2015). Metode Penelitian Bisnis. Medan: UMSU Press.

Kreitner, R., \& Kinicki, A. (2009). Organizational Behavior (Kelima). Jakarta: PT. Salemba Empat.

Luthans, F. (2006). Perilaku Organisasi (10th ed.). Yogyakarta: Andi Offset.

Luthans, F. (2016). Perilaku Organisasi. Yogyakarta: PT. Andi.

Maharani, R. H. (2016). Pengaruh Etika Kerja Dan Knowledge Sharing Terhadap Kinerja 
Pegawai pada Bank Rakyat Indonesia (Persero),Tbk Cabang Jombang. Jurnal Ilmu Manajemen (JIM), 4(1), 302-309.

Mangkunegara, A. (2011). Manajemen Sumber Daya Manusia Perusahaan. Bandung: PT Remaja Rosdakarya.

Mangkunegara, A. A. P. (2014). Evaluasi Kinerja SDM/SM-17. Bandung: PT Refika Aditama.

Mangkunegara, A. P. (2011). Manajemen Sumber Daya Manusia Perusahaan. Bandung: PT. Remaja Rosdakarya.

Moeheriono. (2012). Pengukuran Kinerja Berbasis Kompetensi. Jakarta.

Mulyadi, R. (2012). Terhadap Turnover Intention Pegawai Pada Pasar Modern Pasir Pengaraian. 1-7.

Nasution, E. H., Musnadi, S., \& Faisal, F. (2018). Faktor-Faktor Yang Mempengaruhi Kepuasan Kerja Dan Dampaknya Terhadap Kinerja Pegawai Kanwil Direktorat Jenderal Kekayaan Negara Aceh. Jurnal Magister Manajemen, 2(1), 123-134.

Nazir, M. (2011). Metode Penelitian (6th ed.). Bogor: Ghalia Indonesia.

Novrianto, A. (2019). Pengaruh Kepribadian, Orientasi Kerja Dan Penempatan Pegawai Terhadap Kinerja Pegawai Bank Nagari Cabang Utama Kota Padang. EKOBISTEK, $8(2), 49-55$.

Rahadi, D. R. (2010). Manajemen Kinerja Sumber Daya Manusia. Malang: Tunggal Mandiri Publishing.

Rasjid, E., \& Maramis, D. (2017). Pengaruh Pemberdayaan Dan Kepuasan Kerja Dalam Meningkatkan Kinerja Pegawai Di Lingkungan Politeknik Manado. Proseding Setrinow, 72-83.

Robbins, S P, \& Judge, T. A. (2013). Perilaku Organisasi: Organizational Behavior. Jakarta: Salemba Empat.

Robbins, Stephen, M., \& Coulter, P. (2012). Management (Eleventh). Jakarta: England.

Robbins, Stephen P., \& Judge, T. A. (2015). Perilaku Organisasi. Jakarta: Salemba Empat.

Robbins, Stephen P, \& Judge, T. A. (2008). Perilaku Organisasi. Jakarta: Salemba Empat.

Rondo, D. W. R., Koleangan, R. A. M., \& Tawas, H. (2018). Pengaruh Kepribadian, Lingkungan Kerja Dan Penempatan Kerja Terhadap Kinerja Pegawai (Pada PT. BPR Prisma Dana Manado). Jurnal EMBA, 6(4), 2848-2857.

Rum, B., Sendow, G., \& Pandowo, M. (2019). Pengaruh Etika Kerja , Keterlibatan Kerja Dan Kepribadian Terhadap Kinerja Pegawai Pt . Telkom ( Persero ) Area Manado the Influence of Work Ethics, Job Involvement and Personality on Employee Performance At Pt . Telkom ( Persero ) Manado Area. Jurnal EMBA, 7(1), 591-600.

Safaria, S. (2013a). Pengaruh Keterlibatan Kerja Terhadap Kinerja Pegawai. Manajemen Dan Bisnis, 1 No. 1, 1-17.

Safaria, S. (2013b). Pengaruh Keterlibatan Kerja Terhadap Kinerja Pegawai Pada PT. Seascape Surveys Indonesia. E-Jurnal Manajemen Dan Bisnis, 1 no 1.

Sarjana, S. (2014). Pengaruh Kepemimpinan dan Kerjasama Tim Terhadap Etika Kerja Guru SMK. Jurnal Pendidikan Dan Kebudayaan, 20 (2), 234-250.

Sedarmayanti. (2011). Manajemen Sumber Daya Manusia,Reformasi Birokrasi dan Manajemen Pegawai Sipil (Cetakan ke). Bandung: PT. Refika Aditama.

Simajuntak, P. J. (2011). Manajemen dan Evaluasi Kinerja. Jakarta: Fakultas Ekonomi Universitas Indonesia.

Sinamo, J. (2011). Delapan Etos Kerja Profesional. Jakarta: Institut Mahardika.

Sugiyono. (2015). Metode Penelitian Administrasi Dilengkapi dengan Metode $R \& D$. 
The Influence of Work Ethics, Work Involvement and Personality on Employee Performance virzaerika@gmail.com

Bandung: Alfabeta.

Sugiyono. (2018). Metode Penelitian Kuantitatif, Kualitatif dan R\&D. Bandung: Alfabeta. Sutrisno, E. (2010). Budaya Organisasi. Jakarta: Kencana Prenada Media Group.

Tasmara, T. (2002). Membudayakan etos kerja Islami. jakarta: Gema Insani.

Tika, P. (2006). Budaya Organisasi Dan Peningkatan Kinerja Perusahaan. Jakarta: Bumi Aksara.

Wardhani, A. P., Hasiolan, L. B., \& Minarsih, M. M. (2016). Pengaruh Lingkungan Kerja, Komunikasi Dan Kepemimpinan Terhadap Kinerja Pegawai ( Studi Kasus Di Dinas Kebudayaan Dan Pariwisata Kota Semarang). Journal Of Management, 2(2).

Widyacahya, F. (2018). Pengaruh Pengawasan dan Kondisi Kerja terhadap Keterlibatan Kerja Pegawai Rumah Sakit Mata Undaan Surabaya. Jurnal Administrasi Kesehatan Indonesia, 6(1), 21. https://doi.org/10.20473/jaki.v6i1.2018.21-26

Yakup, Y. (2017). Pengaruh Keterlibatan Kerja, Budaya Organisasi dan Motivasi Kerja terhadap Kepuasan Kerja Pegawai. Perisai : Islamic Banking and Finance Journal, 1(3), 273. https://doi.org/10.21070/perisai.v1i3.1112 